\title{
A comparison of Japan and Vietnam legal approaches to derivative suits
}

\author{
Lien Dang Phuoc Hai*
}

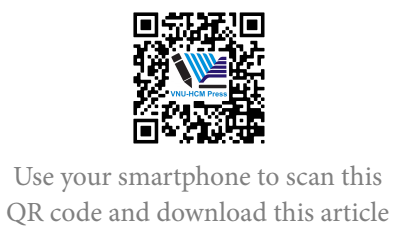

\begin{abstract}
Derivative suits are claims brought by a shareholder or a group of shareholders on behalf of the company to redress for wrongdoings of the directors when those in the company's control refuse to assert a claim usually because of a conflict of interest. The derivative suit is not only to seek recovery of damages by a plaintiff shareholder but also serves as a further threatening tool that can be a possible deterrent to the neglect of duties by directors and other officers of the company. In Vietnam, the derivative suit mechanism was first adopted by Vietnamese corporate law since Decree No. 102/2010/ND-CP (Decree 102) under the term "Shareholder's right to sue members of the Board of Management and/or Director (General Director)", rather than "derivative suit". The regulatory framework for derivative suits has since been revised and contemplated under the latest Law on Enterprises of Vietnam, which was passed by the National Assembly in 2014. Under this scheme, a shareholder or a group of shareholders holding at least one percent (1\%) of the total number of ordinary shares in a Joint Stock Company (JSC) for six consecutive months may bring a lawsuit on behalf of the company against the directors who breach their duties. Still, the practicability and usability of this derivative suit mechanism seem questionable because of a plethora of defects and shortcomings in the statutory derivative suit along with the lack of interest in litigation on the part of shareholders. This article undertakes the analytical review of the substance of the statutory derivative suit in Vietnam and Japan and from the comparison between the two systems, provides recommendations to improve the Vietnamese legislation.
\end{abstract}

Key words: Derivative suits, shareholder, liability, fiduciary duty, cost

University of Economics and Law, VNU-HCM

\section{Correspondence}

Lien Dang Phuoc Hai, University of Economics and Law, VNU-HCM

Email: Haildp@uel.edu.vn

History

- Received: 25/8/2019

- Accepted: 10/12/2019

- Published: 30/6/2020

DOI : 10.32508/stdjelm.v4i2.626

\section{Check for updates}

\section{Copyright}

(c) VNU-HCM Press. This is an openaccess article distributed under the terms of the Creative Commons Attribution 4.0 International license.

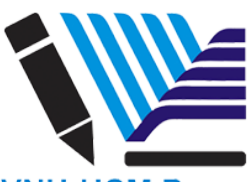

VNU-HCM Press to sue in nature belongs to the company rather than its shareholders. However, since the company is unwilling to exercise their rights because of the conflict of interest, shareholders must derivatively assert this right on behalf of the company ${ }^{1}$.

In addition to the function of loss recovery to the company, the derivative suit also serves as a threatening tool that can be a possible deterrent to the neglect of duties by directors and other officers of the company because the directors and other officers of money, prestige or even their job can be deprived after the triumph of derivative suits brought by the shareholders ${ }^{2,3}$.

In Vietnam, though it is still debatable whether the nature of lawsuits provided in Decree 102 can be considered as derivative suits, Decree 102 is the first legal document which allowed shareholders to sue managers who breached the fiduciary duties and harm the interest of the company and to seek the legal remedy for the company's benefit. After its promulgation, there were no official derivative suits instituted by shareholders that are recorded. An important milestone for the development of the derivative suit
aSome examples of direct claims include the refusal to allow inspection of books and records, the deprivation of shareholders' voting rights, the declaration of dividends, etc.
Cite this article : Hai L D P. A comparison of Japan and Vietnam legal approaches to derivative suits. Sci. Tech. Dev. J. - Eco. Law Manag.; 4(2):745-753. 
in Vietnam was the effectiveness of the 2014 Enterprise Law that introduced the reform for the statutory derivative suit in the hope that the shareholder derivative suits will likely serve as an important tool for promoting corporate governance in Vietnam. Subject to the 2014 Enterprise Law, a shareholder or group of shareholders owning at least one percent of the total number of ordinary shares in a JSC for six months are entitled, on behalf of the company, to initiate legal action regarding civil liability against members of the Board of Management (BOM), the director and/or general director who breach their duties. In doing so, litigation costs shall be borne by the company, except where the petition initiating legal action by the shareholder is rejected. Despite the improved regulation, derivative suits remain unpopular in Vietnam. There is no robust increase in the derivative lawsuit, which can become an incentive for shareholders to commence a lawsuit on behalf of the company to pursue the directorial accountability.

Japan is probably regarded as a prominent example of transplanting the derivative suit under the pressure of the U.S. after World War $\mathrm{II}^{\mathrm{b}}$. As of the transplantation of the derivative mechanism into the Japanese corporate legal regime, this mechanism was moribund for more than forty years. The aggregate number of shareholders' derivative suit between 1950 and 1993 was only thirty-three ${ }^{2}$. There was a consensus of some scholars that the reason for Japanese shareholders had chosen not to use derivative suits, not because of cultural mores, but mainly because of high filing fees ${ }^{4}$. The scenario of the derivative suit in Japan had changed in the early 1990s. The financial crisis in the mid of 1980s had partially paved the way for the upsurge of derivative litigation in Japan. Most importantly, the reduction of the filing fee in the derivative suit explained much of the robust use of the derivative suit in $1993^{\mathrm{C}}$. Interestingly, in the wake of this legal reform, the number of derivative suits skyrocketed. More specifically, in Japan, while there had been only 84 suits pending in 1993, there were 286 by the end

\footnotetext{
${ }^{\mathrm{b}}$ Mathias Siems. Convergence in Shareholder Law. New York: Cambridge University Press; 2008; p.317.

${ }^{c}$ During the economic bubble, equity finance which diluted the share of existing shareholders was used by companies. Since the bubble burst, many companies were thus left with massive debts. Therefore, shareholders had good reason to pursue the directorial accountability. Hiroshi Oda. Japanese Law. 3rd ed. Oxford: Oxford University Press; 2009; p.253-256. West, in his research, also believed that the burst of the "bubble economy" in the early 1990s may also account for some of the increase of derivative suits. Specifically, he argued that lower the cost of suing makes it easier to pursue the derivative suit of shareholders. The post-Bubble decline in the Japanese economy may also influence some cases, as plaintiffs may find it easier to prove damages against flailing firms. West, Mark D. Why shareholders Sue: Evidence from Japan. Journal Legal Studies 2001; 30:351-382.
}

of 1999. Among other cases, Daiwa case was probably one of the highest amounts of damages acknowledge by the court before 2008 where the Osaka District Court, in a voluminous decision, ordered eleven current and former directors of Daiwa Bank to pay a total of 775 million US dollars' worth of damages ${ }^{2,5}$.

\section{THE COMPARISON STUDY OF STRUCTURE OF THE DERIVATIVE SUIT IN JAPAN AND VIETNAM}

\section{Quorum Requirements}

Japan is a notable exception case where shareholders can initiate the derivative suit without any requirements with regard to holding a minimum percentage of shares ${ }^{6}$. Subject to the Company Act, the shareholder requirement to initiate a derivative suit is to hold the shares (more than one share) for at least 6 consecutive months prior to making a demand to the company to initiate an action to pursue the liability of directors and other officers. If the company refuses to commence a lawsuit or it fails to file such lawsuit within sixty days from the day of the demand, the shareholder who has made such demand may file a lawsuit on behalf of the company (Article 847). In addition, contemporaneous ownership ${ }^{\mathrm{d}}$ is not a condition for derivative suits. In other words, it is unnecessary for a shareholder to have its shares at the time of the alleged wrongful act of a director. However, if the shareholder ceases to be a shareholder during the derivative suit, the lawsuit will be dismissed unless the shareholder fulfils one of the exceptional conditions under which he or she has lost the status of shareholder such as in a merger (Article 851).

In Japan, it is popular for shareholders to take advantage of their shares to disrupt the company's operation for a variety of purposes (such as lowering the stock price or seeking a pay-out) by sokaiya in the manner of a settlement with the corporation or director sued in Japan ${ }^{7}$. A sokaiya is usually a nominal shareholder who either attempts to extort money from a company's managers by threatening to disrupt its annual shareholders' meeting with embarrassing or hostile questions or who works for a company's management to suppress dissent at the meeting ${ }^{5}$. The sokaiya often has a close relationship with yakuza (Japanese

\footnotetext{
${ }^{\mathrm{d}}$ In most jurisdiction in the United States, the contemporaneous ownership requirement in a derivative require that a plaintiff must have been a shareholder at the time of the misconduct infringing the company's interest occur and must remain a shareholder pending the outcome of the litigation. See Seth Aronson, Sharon L. Tomkins, Ted Hassi \& Tristan Sorah-Reyes. Shareholder Derivative suits: From Cradle to Grave, in Lyle Roberts, David Siegel, Jerome F. Birn Jr., Jonathan K. Youngwood. Securities Litigation \& Enforcement Institute; 2009.
} 
mafia). In the history of derivative suits, the sokaiya commenced a tremendous number of derivative suits in Japan ${ }^{8}$. For this reason, the right to demand the company to commence a lawsuit is not available to shareholders who seek unlawful gains for themselves or a third party or seek to inflict damage on the company under that lawsuit (Article 847 para. 1 of the 2005 Company Act).

The prevailing statutory scheme in Vietnam also limits the rights of shareholders to bring derivative suits against the company. Comparatively, a prerequisite to a shareholder or a group of shareholders initiating a derivative suit against the member of the BOM or the director or general director is to own at least one percent $(1 \%)$ of the number of ordinary shares in the JSC for six consecutive months. The prerequisite to the shareholder eligible for the derivative suit still keeps unchanged from Decree 102 to the 2014 Enterprise Law. Notably, there is no regulation requiring a shareholder to have its shares at the time of the alleged wrongful act of directors, provided that the shareholder has held such share for a period at least six consecutive months prior to the making of such demand upon the company. Therefore, to some extent, Vietnamese law imposes stricter requirements for shareholders to launch derivative lawsuits than in Japanese law.

\section{Who Can Be Sued?}

In Japan, as directors of a stock company owe a fiduciary duty to the company and shareholders, when a director breaches his duty set forth by the law, he is liable vis-à-vis the company for damages and it is prerogative of the company to sue the director for resultant damages ${ }^{9}$. The right to pursue the liability of directors of the company is also a ground for exercising a shareholder derivative suit. Regarding exemption of liability, if directors can demonstrate that they did not fail to exercise their duty of care in the performance of their duties, they will not be held individually liable. Although the Japanese law does provide the derivative suit to assist in supervising the responsibilities and duties of the corporation's board and officers whether the classical or committee structured company ${ }^{10}$, the

${ }^{\text {e}}$ Subject to Article 423 of the 2005 Company Act, if a director, accounting advisor, company auditor, executive officer or accounting auditor ("Officers, Etc.") neglects his/her duties, he shall be liable to such stock company for damages arising as a result thereof. Moreover, the liability of directors also mentions in other provision of the 2005 Company Act, for example, offering illegal profits regarding the exercise of the shareholder's right is contemplated forth in Article 120 of the 2005 Company Act or illegal distributions of surplus dividends or repurchase of shares that exceed the distributable amount under the 2005 Companies Act at the time of that distribution or repurchase of shares set forth in Article 212 of the 2005 Company Act. derivative suit can be initiated by shareholders on behalf of the company against not only directors but also accounting adviser, corporate auditors, senior executive, accountants, founders, directors and corporate auditors in the established procedures and liquidators (Article 857 of the 2005 Company Law). Comparing with the former provisions where the derivative suit was available only against directors, the 2005 Company Law expanded the scope of people whose liability can be pursued by a derivative suit. However, if the action is intended for the unjust benefit of the plaintiff shareholder, or a third party, or to cause damage to the company, this law does not apply.

From the Vietnamese perspective, though a derivative suit can be brought against not only president of the BOM, director, legal representative but also other managers who commit violations against the manager's duties provided by the law in a limited liability company (Article 72 of the 2014 Enterprise Law), the persons who can be sued for civil liabilities in the JSC are only the members of the BOM and/or the director (general director). This is a more limited approach than that found in Japan. As such, shareholders are not entitled to file a lawsuit against other managers such as accounting advisers, corporate auditors, senior executives, accountants as provided in Japanese law.

To pursue a derivative lawsuit against the directors and members of the BOM, the infringement of their duty is a prerequisite. Vietnamese law provides specific circumstances in which the derivative suit can be triggered by shareholders against the directors and members of the BOM for civil liabilities, including (i) failing to perform given rights and obligations honestly and prudently to the best of his/her ability and in the best interests of the company and shareholders (ii) failing to implement or to completely implement Resolutions of the BOM; or Resolutions of the General Meeting of Shareholders; (iii) perform given rights and obligations against the law, the company's charter, or Resolutions of the General Meeting of Shareholders; (iv) uses information, secrets, business opportunities of the company for self-seeking purposes or serving the interest of other entities; (v) abuses the position, power, or assets of the company for selfseeking purposes or serving the interest of other entities; and (vi) other cases prescribed by law and the company's charter ${ }^{f}$. In light of the indicated circumstances, it could be said that Article 161 of the 2014

${ }^{\mathrm{f}}$ In Vietnam, as opposed to defining the duty of care, the law provides that the members of the BOM and the director have the responsibilities to exercise his powers and duties honestly and prudently to the best of his ability and in the best interests of the company and shareholders (Article 160 of the 2014 Enterprise Law). It should be 
Enterprise Law which lists the specific circumstances where the derivative suit can be triggered, is an open provision. The lawmakers are ambitious to extend the scope of the derivative suit by way of providing that breaching not only any specific circumstance set forth in Article 161 but also other cases prescribed by law and the company's charter is also a cause of action for derivative suits. As such, depending on the company's charter, members of the BOM and directors may also be sued by shareholders in case of his infringement of any obligations, whether recorded in the company's internal documents such as the charter or the law. In addition, the legal grounds for pursuing a derivative suit have not yet mentioned the damage resulted in the wrongful act of a director or member of the BOM. In other words, provided that any violation of a director and a member of the BOM happens, the shareholder is entitled to sue on behalf of the company, regardless of whether actual damage has arisen from the infringing actions or not. However, in practice, even when the law does not require the damage as an element in derivative suits, the shareholders must prove the wrongful acts of the directors or members of the BOM, which cause damage in the trial ${ }^{11}$.

\section{The Demand Requirement}

A theoretical perspective explains that since derivative suits are naturally derived from the rights belonging to the company, as an entity directly suffers from the misconducting behaviour of directors, it is often permitted to commence a derivative action by the shareholder if the company decides, as its creation, not to start a legal action upon its assessment of the case's merits or any other reasons.

In Japan, prior to bringing a derivative suit, the shareholder must make a demand, in writing or any other method set forth by the law, for the company to file the action for compensation for alleged breaches or damage in its own name ${ }^{g}$. If the company refuses to commence such suit within sixty days of the demand, the shareholder who made the demand is entitled to initiate an action on behalf of the company. As such,

noted that "prudently" in this case equates to the care and diligence. This is the most sophisticated wording set down for the JSC in connection with the care and diligence. See Jeremy Seymour Pearce. Directors' Powers and Duties in Vietnam [Ph.D thesis]. Bond University Faculty of Law; 2009. Moreover, like the duty of care, the duty of loyalty is also understood in the same manner. That is, the members of the BOM, the (general) director have the responsibilities to act in the best interest of the company and shareholders; do not use information, secrets, business opportunities of the company; do not misuse the position, power, or assets of the company for self-seeking purposes or serving the interest of other entities. Therefore, breaching the fiduciary duty is one of the conditions for the shareholders to initiate the derivative lawsuit under the Vietnamese corporate law.

${ }^{g}$ Article 847 of the 2005 Company Act. even in the case that the company refuses the demand to prevent a strike suit, the shareholder may still bring a derivative suit after the rejection of the company. Given that, the company cannot stop a derivative suit from being bought by the plaintiff shareholder even though it is a lawsuit without merits. Consequently, there may be the case where the company's reputation is hurt even though the unmeritorious case is rejected after the court's investigation. For this reason, scholars believe that, in the case of Japan, the demand requirement is merely procedural $^{3,12}$. In the case of an emergency where there is a likelihood of irrecoverable loss caused to the company, the eligible shareholder may initiate the derivative suit without such request. In Vietnam, there is no statutory requirement to file a demand requesting the BOM or Board of Supervision (BOS) to initiate a lawsuit before the shareholder commences a legal action on behalf of the company. Comparing to other countries, such as Japan and Korean $^{\mathrm{h}}$, under Vietnamese law, provided that there are breaches of director's duty, the eligible shareholder may file civil lawsuits on behalf of the company regardless of the board's approval.

\section{Litigation Costs}

Since the derivative suit asserts a right on behalf of the company rather than the individual shareholders, any awards or settlements recovered typically go to the company, instead of to an individual shareholder. However, the shareholders will also get a pro rata benefit indirectly through the increase of the book value of their stock. Meanwhile, the direct suit's recovered damages will belong to the individual shareholder who has his legitimate interests infringed upon. Due to this difference, the payment of litigation costs from the derivative suit and the direct suit is charged to different claimants. When requests under a derivative suit brought by shareholders are accepted by the court, the litigation cost shall be borne by the company rather than the claimant shareholder as in the direct suit. In the context of Japan, the reimbursement of litigation costs, including filing fees and lawyer fees by the company is statutorily stipulated in the corporate lawi. Previously, the filing fee for the derivative lawsuit was determined by the amount in dispute, which is the amount of damage sought by the plaintiff. Consequently, the filing fee presented a major deterrent from filing a derivative suit as it was substantial

\footnotetext{
${ }^{\mathrm{h}}$ In Korea, the RMBCA and the ALI's Principles of Corporate Governance provided, and a plaintiff shareholder should wait for 30 days. Only if the demand and waiting 30 days for board's response might cause the company irreparable damage, shareholders can bring a suit without demand on board.

${ }^{\mathrm{i}}$ Article 852 para. 1 of the 2005 Company Act.
} 
if the damages sought were high ${ }^{7}$. In 1993, a major change regarding the calculation of the court fee to the derivative lawsuit led to a significant reduction of the filing fee. The Commercial Code was amended to provide in Article 267 para. 4 that the derivative suit was to be deemed an action relating to a claim which is not a claim based on a property right in calculating the value of the subject-matter of the suit. As a result, the value of the subject-matter of the dispute was to be determined as a non-property claim in accordance with Article 4 para. 2 of the Law on the Fee of Civil Lawsuits.

Concerning the litigation costs in the derivative action, Article 852 para. 1 of the 2005 Company Act provides that if a shareholder who has filed a lawsuit pursuing the director's liability prevails with the derivative suit, the shareholder may demand the company to pay a reasonable amount including the necessary costs (excluding court costs paid by the shareholder $)^{j}$ or fee to an attorney or a legal profession corporation with respect to the derivative lawsuit, on the condition that the amount is not exceeding the amount such cost or the amount of such fee. As such, the necessary costs or the lawyer's fee of the derivative suit shall be borne by the company if the case is successful and these fees, in general, shall be accepted if reasonable, not exceeding the amount of such cost or the amount of such fee. Despite that, it is quite difficult to determine precisely what constitutes a "reasonable amount" in practice due to the lack of cases litigated to final judgment even after the 1993 Commercial Code revisions ${ }^{5}$.

Comparatively, in Vietnam, litigation expenses in connection with the derivative lawsuit are mainly composed of the court's fee (including the advanced court fee ${ }^{\mathrm{k}}$ and the fees incurred during and after hearing of the case e.g. fee for issuance of copies of court judgments and ruling) and the lawyer's fee.

Under the Vietnamese litigation system, there are two kinds of claims including non-property and property. For non-property claims (e.g. claims for the return of properties under others' management), the court fee, in this instance, is a fixed amount ${ }^{1}$. For property

\footnotetext{
j In the context of Japan, the defeated party bears the court costs, subject to Article 61 of the Japanese Civil Procedure Code. Therefore, in such a case, the court costs will be exempted from the reimbursement of costs by the company to the plaintiff shareholder if the case prevails.

${ }^{\mathrm{k}}$ Article 146.1 of the Civil Procedure Code provides that the plaintiffs, the defendants who have made counterclaims against the plaintiffs and the persons with related rights and interests who have made independent claims in civil lawsuits must advance first-instance court fees; the persons who have made appeals must advance appellate court fees, except for cases where they are exempted from or do not have to pay court fee advances.

${ }^{1}$ Article 27 of Resolution No. 326/2016/UBTVQH14.
}

claims (e.g. seeking compensation for the director's liabilities), the court fee is calculated premised on the amount claimed $^{13}$. Unlike Japan, Vietnamese laws deem the court fee in the derivative suit as a property claim, the plaintiff shareholder shall, therefore, pay a contingent incremental fee, as opposed to a fixed fee $^{\mathrm{m}}$. For litigation costs, Article 161.1 of the 2014 Enterprise law provides that the litigation cost shall be borne by the company, except where petition initiating legal action by the shareholder is rejected. In other words, in case of losing the lawsuit, the plaintiff shareholder shall bear the litigation cost regardless of the good faith of his action. Therefore, the plaintiff, in this instance, also takes the risks involved into consideration when deciding to file a lawsuit.

Moreover, because the prevailing law only provides that the litigation cost shall be borne by the company, but does not clarify what kinds of cost, especially legal fee, will be categorized as litigation cost, the Civil Procedure Code, therefore, shall be applied to determine the lawyer's fee ${ }^{n}$. As such, each party shall pay its own fees for requesting such lawyers, except otherwise agreed upon by the parties (Article 168.3 of the 2015 Civil Procedure Code). In the derivative lawsuit context, as the shareholder commences an action against the director for the civil liabilities on behalf of the company, the lawyer's fee can be assumed as the part of litigation costs which the company must pay in case that the plaintiff shareholder claim accepted by the court.

\section{Limitations to Prevent Abuse of the Deriva- tive Suits by Shareholders}

The purposes of the plaintiff shareholder's deposition are to secure the recovery of damages caused by the plaintiff shareholder who brought a suit in bad faith and broadly to deter abusive actions ${ }^{14}$. In Japan, in the case where a plaintiff files an action for pursuing liability, the court may, in response to a petition by the defendant, order such the plaintiff to post reasonable security. Besides, when the defendant intends to file the petition in response, the defendant shall make a prima facie evidence showing that the action for pursuing liability has been filed in bad faith. As such,

\footnotetext{
${ }^{\mathrm{m}}$ For this reason, in the research of Quach, she also indicated that subject to this calculation, the potential shareholder plaintiffs will probably hesitate to start a lawsuit mainly due to concerns over costs. See Quach, Quynh Thuy. Transplantation of Derivative suits to Vietnam - Tip-Offs from Absence of Academic Debate. Asian Journal of Comparative Law 2012; 7:1-35.

${ }^{\mathrm{n}}$ Article 161.2 of the 2014 Enterprise Law provides that procedures for proceedings are prescribed by corresponding regulations of law on civil proceedings.
} 
when a case reaches the courtroom, the initially crucial decision is the court's judgment of whether to require a plaintiff to post a bond. Although the bad faith in the derivative suit is not clearly defined under the Commercial Code, the dominant opinion expressed by the Tokyo District Court is that "bad faith" includes cases in which the plaintiffs sued with little hope of success, or that would likely be dismissed by defendants ${ }^{5,14}$.

From the Vietnamese perspective, the law does not require the plaintiff shareholder to post security for the derivative suit. As such, the plaintiff can initiate the lawsuit on behalf of the company without posting security.

\section{POSSIBLE SHORTCOMINGS AND RECOMMENDATION FOR IMPROVEMENT}

\section{The Minimum Shareholding Requirement as a Barrier to Derivative suit}

As indicated earlier, the Vietnamese approach to the derivative suit is not available for the minor shareholders who directly or indirectly own less than one percent of voting stocks of an issuing organization, except for the case where several shareholders get together to meet the requirement. Although the minimum shareholding requirements are generally justified as being means by which frivolous lawsuits may be prevented ${ }^{15}, 0$ in the context of Vietnam, it has been suggested that the requirement of owning one percent by group or individual is a possible barrier to bring a derivative suit. For instance, a minimum share requirement based on the percentage will make it more difficult for shareholders of the large companies or the companies required the high statutory, that is, credit institutions, insurance companies or listed companies, to start a derivative suit than those in small companies ${ }^{\mathrm{p}}$. Thus, holding one percent of ordinary shares of these companies is deemed "far too difficult". Theoretically, shareholders can aggregate

\footnotetext{
${ }^{\circ}$ The minimum shareholding requirement is widely recognized as locus standi rules for taking a derivative suit in civil law jurisdictions. For instance, in Korean, the shareholding threshold for filing a derivative suit was $0.01 \%$ in the case of listed companies and $1 \%$ in the case of non-listed companies or holding $1 \%$ of the statutory capital or shares with a par value of EUR 100,000 in Germany. See the Korean Securities and Exchange Act \$191-13(1), Korean Commercial Code $\$ 403(1)$, Article 148 (1) of the German Stock Corporation Act.

PThe lawful capital requirement for the commercial bank is 3,000 billion Vietnam dong (Decree No. 10/2011/ND-CP), the range from $300-1000$ billion for the lawful capital to the insurance company depending on the types of the insurance business (Decree No 73/2016/ND-CP), or 120 billion Vietnam dong for the company listed in Ho Chi Minh Stock Exchange (Decree 58/2012/ND-CP).
}

their shares to meet $1 \%$ of the shareholding requirement; however, in reality, the cost of coordination of the shareholders to bring a lawsuit will be a big issue. As such, the lack of derivative suits in Vietnam may be first of all attributed to the $1 \%$ minimum shareholding requirement. Therefore, a reduction of the shareholding requirement in listed companies and some specific companies with the high statutory capital such as credit institutions and listed companies shall be first of all taken into consideration ${ }^{\mathrm{q}}$. Keeping in mind that when considering the adoption of a minimum requirement, it is appropriate to consider not only the need to sift out frivolous litigation but also to ensure that meritorious suits are not blocked.

\section{Pre-trial Procedure: Can the Company Com- mence a Lawsuit against the (General) Di- rector or Member of the BOM?}

Previously, the Decree 102 required the shareholder or a group of shareholders holding at least $1 \%$ of ordinary shares for six consecutive months to request the BOS to institute a lawsuit over the civil liability of a member of the BOM or the director. If the BOS fails to institute such suit, or the company has no BOS, the shareholder or group of shareholders may directly institute a lawsuit against a member of the BOM or a director (Article 25). Since the effectiveness of Decree 102 the statutory scheme where the BOS had the power to commence the lawsuit was considered by many commentators a unnecessarily complicated requirements to initiate a law suit ${ }^{\mathrm{r}}$.

${ }^{\mathrm{q}}$ However, the arising issue is that what extend the threshold should be reduced to enable minority shareholders to bring the lawsuit, while still preventing frivolous action? In fact, it is too difficult to set an appropriate threshold requirement because any fixed percentage of shareholding requirement seems arbitrary. In the case of China, Zhang believes that any figure is arbitrary, over-inclusive, and under-inclusive. In the case that lawsuits are brought for nonfinancial considerations, a minimum shareholding requirement is irrelevant. It is impossible to ascertain to what extent the Chinese shareholding requirement should be reduced; on the other hand, there is the legitimate concern that any reduced threshold figure may be too low. See Zhang, Zhong. The Shareholder Derivative suit and Good Corporate Governance in China: Why the Excitement is actually for nothing. Pacific Basin Law Journal 2011; 28(2).

${ }^{\mathrm{r}}$ Nguyen, Khanh Ngoc believes that granting the power to review and initiate the lawsuit to the BOS made it impossible in practice. Also, Hieu, as the vice leader of the Drafting Committee for the 2014 Enterprise Law, criticized that this mechanism makes the procedure for derivative suit more complicated. See Tân Văn. Kiện lãnh đạo doanh nghiệp, cổ đông "bó tay". Đầu tư Chứng Khoán. 7 January 2014. Available from http://tinnhanhchungkhoan.vn/phapluat/kien-lanh-dao-doanh-nghiep-co-dong-bo-tay-84317.html. Notably, Quach is probably one of the most outstanding commentators who supports this mechanism. From her argument, it could be convincing to assume that the mechanism for reviewing the case before the derivative suit is necessary. However, the role of BOS is still vague. Decree 102 does not state any investigation procedures that the BOS needs to conduct upon receiving the shareholders' request. 
This scenario was changed in the 2014 Enterprise Law in the manner that does not require eligible shareholders to file a demand to the company to pursue action against managers prior to commencing a derivative suit on behalf of the company. Thus procedures to review the merits of the case filed by the plaintiff shareholder in a derivative suit seem absent.

It is much better if the Vietnamese law grants companies a chance to review any given cause of action that is available, and might decide to or not to pursue action against directors at its own discretion. The rational reason is that the company, as the entity separated from the shareholders and suffered directly from the damages caused by breaching of the directorial accountability, is entitled to learn about such breach and might decide whether to commence litigation for pursuing civil liabilities upon taking all relevant factors, such as the compensation value, litigation fee, reputation into account. It is reasonable for shareholders to initiate a lawsuit, on behalf of their company, after the company fails to bring such suit. Secondly, comparing to Japanese law, Vietnamese law does not require the plaintiff shareholder to notify the company about the lawsuit against a director or a member of the BOM on behalf of the company. For this reason, it is difficult for the company to learn about the derivative lawsuits against its director(s) or member(s) of the BOM soon enough to intervene or stop the lawsuit from being brought even though it is a case without merit. In addition, there are some cases where a director or a member of the BOM has breached their duty under the law, but the company and the alleged director or member of the BOM have reached the agreement out of the court already by a compensation. Therefore, the company should have the right to receive the demand of the shareholder and initiate the case first, even if they fail to initiate the lawsuit.

\section{Litigation Costs: Lack of Incentive for Shareholders}

In Vietnam, the court fee in the derivative suit as a property claim calculated based on the percentage of the quantum of the claim, which is determined by the court. If the shareholder loses the case, he must

If the BOS merely works as a disinterested organ to challenge the company's managers on behalf of the company, the law still leaves two unresolved matters including what grounds can the BOS refuse the shareholders' request to bring the case, and if we assume that the BOS refuses to bring the case because it does not serve the best interest of the company, does such a decision of the BOS carry any weight in determining while the shareholders may still bring the case after the BOS' refusal to sue? See Quach, Quynh Thuy. Transplantation of Derivative suits to Vietnam - Tip-Offs from Absence of Academic Debate. Asian Journal of Comparative Law 2012; 7:1-35. bear the litigation cost and in that instance, it would have cost him an enormous amount. This approach seems to be unreasonable, according to some scholars, because it is accepted that the derivative suit does not bring the direct monetary benefit for the plaintiff shareholder themselves ${ }^{13}$, and the recovered amount accrues to the company as a whole with the plaintiff shareholder benefiting only small pro rata share of any award. To provide some incentive for shareholders I agree with one suggestion that the law should regard the litigation cost that is the court fee, as a non-property claim, rather than a property claim ${ }^{13}$ because of two main reasons: First, if it deems to be a property claim, the fee that the plaintiff ultimately bear if he or she loses can be extremely high, as the quantum of the damage in the derivative suit tends to be large. However, if the derivative suit deems to be a non-property claim, then the fee will be set as a nominal flat rate. Second, subject to the Civil Procedure Code, those who initiate litigation must pay in advance a portion of court fee. Therefore, the shareholder plaintiff, who filed a lawsuit even on behalf of the company must pay the advance court fee. If the derivative suit is categorized as a non-property claim, the shareholder is only required to pay the advance court fee equal to the court fee. In such a case, the court fee advanced will likely be an insignificant amount (equal to the cost fee for the non-property claim). The hurdle in relation to cost fee borne by shareholders is therefore removed.

\section{CONCLUSION}

The derivative suit mechanism has recently been developed as a powerful weapon in the shareholder's arsenal to combat the director's corporate misconduct in many Asian countries. Japan becoming a leader in the number of derivative suits is concrete evidence for the effectiveness of this mechanism in even nonlitigious countries. In some respects, Japan's experience can shed light on the re-evaluation of Vietnamese prevailing law after its significant reform in the 2014 Enterprise Law. The major considerations should be: first, to require a shareholder to file a demand to the company to initiate the lawsuit prior to filing a lawsuit on behalf of the company; second, the quorum requirement for the shareholders to initiate the derivative suit being one percent of ordinary shares should not be applied for shareholders in the listed company and other special types of companies prescribed by law; third, the filing fee in the derivative suit should be premised on a non-property claim as it is at the moment to facilitate shareholders to bring an action on behalf of the company to pursue the liability of directors. 


\section{ABBREVIATIONS}

BOM: Board of Management

BOS: Board of Supervision

Decree 102: Decree 102/2010/ND-CP

JSC: Joint Stock Company

\section{COMPETING INTERESTS}

The author declare that they have no conflict of interest.

\section{AUTHORS' CONTRIBUTIONS}

Lien Dang Phuoc Hai has done all works of the article as a sole author.

\section{REFERENCES}

1. Stephen MB. Corporation Law and Economics. Foundation Press, New York: Foundation Press, University Textbook Series. 2002;p. 362.

2. Oda H. Japanese Law. 3rd ed. Oxford: Oxford University Press. 2009;p. 253-256.

3. Ok-Rial S. Improving Corporate Governance Through Litigation: Derivative Suits and Class Actions in Korea, in Hideki Kanda, Kon-Sik Kim and Curtis J. Milhaupt, eds. Transforming corporate governance in East Asia Transforming Corporate Governance in East Asia. London: Routledge. 2008;p. 91115.

4. West MD. The Pricing of Shareholder Derivative suits in Japan and the United States. Northwestern University Law Review. 1994;88:1436-1474.

5. West MD. Why shareholders Sue: Evidence from Japan. Journal Legal Studies. 2001;30:351-382. Available from: https: //doi.org/10.1086/322056.

6. Puchniak D. The Complexity of Derivative suit in Asia, in D. Puchniak, H. Baum, \& M. Ewing-Chow (Eds.). The Derivative suit in Asia - A Comparative and Functional Approach. Cambridge: Cambridge University Press. 2012;p. 90-127. Available from: https://doi.org/10.1017/CBO9780511998027.004.

7. Arno LE. Limitations on Derivative suits in Germany and Japan to Prevent Abuse. Journal of Japanese Law. 2012;17(34):199227.

8. Puchniak DW, Nakahigashi M. Japan's Love for Derivative suits: Irrational Behavior and Non Economic Motives as Rational Explanations for Shareholder Litigation. Vanderbilt Journal of Transnational Law Jan. 2012;45(1):7-8.

9. Bruce EA. Learning from Comparative Law in Teaching U.S. Corporate Law: Director's Liability in Japan and the U.S. Penn State International law Review. 2013;22(213).

10. Carl FG. The Rules of Law in Japan: A Comparative Analysis. The Hague, The Netherlands: Kluwer Law International. 2008;p. 279.

11. Quang TN. Enterprise Law Principles. Dan Tri publishing House. 2016;p. 282.

12. Gen G. Legally "Strong" Shareholders of Japan. Michigan Journal of Private Equity and Venture Capital Law. 2014;3:125-163.

13. Quach QT. Transplantation of Derivative suits to Vietnam Tip-Offs from Absence of Academic Debate. Asian Journal of Comparative Law. 2012;7:29. Available from: https://doi.org/ 10.1515/1932-0205.1390.

14. Takahashi K. Japan - Shareholder derivative suit: safeguards against abuse. Amicus Curiae. 1998;7:31-32. Available from: https://doi.org/10.14296/ac.v1998i7.1587.

15. Zhang Z. The Shareholder Derivative suit and Good Corporate Governance in China: Why the Excitement is actually for nothing. Pacific Basin Law Journal . 2011;28(2). Available from: https://doi.org/10.2139/ssrn.2641863. 


\title{
So sánh pháp luật Nhật Bản và Việt Nam về khởi kiện phái sinh
}

\author{
Liên Đăng Phước Hải*
}

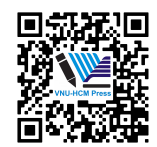

Use your smartphone to scan this QR code and download this article

\section{TÓM TẮT}

Kiện phái sinh là vụ kiện được tiến hành bởi một, hoặc một nhóm cổ đông nhân danh công ty, nhằm mục đích khắc phục những sai phạm từ người quản lý, khi những người này đã từ chối việc khởi kiện do các xung đột về lợi ích. Các vụ kiện phái sinh được tiến hành, không chỉ nhằm khôi phục lại những thiệt hại gây ra bởi những người quản lý trong công ty, mà còn là một biện pháp nhẳm răn đe, phòng ngừa những hành vi sai phạm từ họ. Tại Việt Nam, chế định kiện phái sinh được ghi nhận lần đầu trong Nghị định 102/2010/NE-CP hướng dẫn thi hành Luật doanh nghiệp 2005 dưới tên gọi " Quyền khởi kiện thành viên Hội đông quản trị, Giám đốc (Tổng Giám đốc)". Sau đó, khung pháp lý về khởi kiện phái sinh được chỉnh sửa và ghi nhận chính thức trong Luật Doanh nghiệp, được Quốc hôii thông qua chính thức vào năm 2014. Theo đó, cổ đông hoặc một nhóm cổ đồng sở hữu ít nhất 1\% cổ phần phổ thông liên tục trong 6 tháng, có quyền nhần danh công ty cổ phần khởi kiện những người quản lý đã vi phạm nghĩa vụ của mình. Mặc dù vậy, tính khả thi và hiệu quả của chế định khởi kiện phái sinh tại Việt Nam dường như vẫn còn nhiêu hoài nghi, bởi do những hạn chế trong quy định pháp luật cùng với sự thiếu quan tâm đến của cổ đông về chế định khởi kiện này. Trong bài viết này, tác giả sẽ phân tích những quy định của Việt Nam và Nhật Bản về thủ tục khởi kiện phái sinh. Từ kết quả so sánh, những bình luận cũng như những giải pháp được tác giả đề xuất nhằm nâng cao khả năng thực thi thủ tục khởi kiện phái sinh tại Việt Nam.

Từ khoá: Kiện phái sinh, cổ đông, trách nhiệm, nghĩa vụ ủy thác, chi phí
Trường Đại học Kinh tế-Luật, Đại học Quốc gia TP.HCM

\section{Liên hệ}

Liên Đăng Phước Hải, Trường Đại học Kinh tế-Luật, Đại học Quốc gia TP.HCM

Email: Haildp@uel.edu.vn

Lịch sử

- Ngày nhận: 25/8/2019

- Ngày chấp nhận: 10/12/2019

- Ngày đăng: 30/6/2020

DOI : 10.32508/stdjelm.v4i2.626

\section{Check for updates}

\section{Bản quyền}

๑ ĐHQG Tp.HCM. Đây là bài báo công bố mở được phát hành theo các điều khoản của the Creative Commons Attribution 4.0 International license.

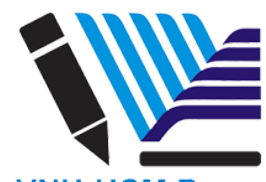

VNU-HCM Press
Trích dẫn bài báo này: Hải L D P. So sánh pháp luật Nhật Bản và Việt Nam về khởi kiện phái sinh. Sci. Tech. Dev. J. - Eco. Law Manag.; 4(2):745-753. 